\author{
Бојан М. Томић \\ Универзитет у Београду, Институт за мултидисциплинарна истраживања \\ Међународни иентар за православне студије, Ниш \\ e-mail: bojantomic@imsi.rs
}

\author{
Милица М. Томић \\ Београд - Србија \\ e-mail: tomic.milica.bg@gmail.com
}

\title{
КРАЈЊИ ПАРАДОКСИ ЦРНОГ И БЕЛОГ
}

Апстракт: У цุиљу расветљавања парадоксалности антиномичног пара црно и бело до сада је испитивано нихово појављивање у иконопису, науци, митологији, символици, ито је учињено разматрањем кључних чињеница, сазнања и парадигматичних епизода. Сада су истраживања доведена до ерминевтичких лимита, узимајућу у обзир античку митологију, историју науке, библистику и иконографију. Издвојени су технолошко-колористички парадокс, космолошки и астрофизички парадокс, парадокс из епистемологије, те онирички парадокс. Као врхуњење узете су у разматрање иконе Преображења, Распећа и Васкрсења, старозаветни мотив изласка из Египта и библистички мотив Божанског примрака. Да се закључити да истраживања ирног и белог као отворена тема, у сваком времену нуде интегративне и ултимативне могућности и изазове.

Кључне речи: ирно, бело, Божански примрак, облак

\section{Увод}

Током историје опширно се приповедало и записивало о црном и белом. Напоредо са књижевношћу црна и бела су се користиле у процесу сликања. За прве пећинске цртеже карактеристична је употреба угљена, гара, а потврђено је коришћење манган оксида у периоду средњег палеолита од стране неандерталаца. ${ }^{2}$ Однос око-сунце и страх од црног (мрака) уткани су у људско биће на физиолошком, као и на религијском нивоу. ${ }^{3}$

Истраживања о црном и белом која су у протеклој деценији објављена у оквиру Црквених студија обухватила су њихове парадоксе, границе и инспирацију ${ }^{4}$. Разматрање парадокса кретало се од анализе оних једноставнијих који се јављају при проучавању црног и белог од стране космологије и физиологије, до ерминевтички захтевних који се

1 Рад је подржало Министарство просвете, науке и технолошког развоја Републике Србије (Уговор бр. 451-03-68/2020-14/200053).

2 Heyes et al. 2016.

3 Томић 2015.

4 Томић 2012.

Томић, Томић 2013. 
односе на екстреме (лимите и лимесе) тумачења теме црног и белог. Границе црног и белог испитиване су превасходно из домена иконописа, теологије, физике, физиологије, символике и психологије, али и неких других дисциплина. Њихов однос разматран је са различитих становишта од којих су нека диспаратна, а то је учињено и у контексту различитих епоха. У контексту 21-вековне мисли која је субспецијалистички развијена овај однос и даље није довољно проблематизован нити је извршена сврсисходна синтеза досадашњих више-дисциплинарних сазнања. Уз ослањање на претходна истраживања на тему црног (Црног) и белог (Белог) у овом раду је присутно финално и истанчаније излагање у оквиру којег је образложен крајњи теолошки парадокс. Обрађени су претежно примери у чијим су основама мрак који тајанствено исијава и светлост која бива скривена тамом.

\section{Извод из досадашњих истраживања}

Символика црног и белог присутна је у пресудним животним тренуцима и повезује се са препородом, цветањем, васкрсењем, Божанским, уздањима, вером, узвишеношћу, највећим вредностима друштва, чистотом, миром, али и са страховима, деструктивним побудама, трагедијама, болестима, неуспесима, самоубиствима, утварама и духовима. ${ }^{5}$ Њихова символика је често у антиномичмом пару. ${ }^{6}$ Бела је перципирана првенствено као символ чистоте, невиности и радости испуњења духовног живота, каква је садржана, на пример, у представи душа у Откривењу које су у белим одеждама (Отк 3 , 4; 7, 9). Насупрот томе, одежде које носе невесте у Јапану беле су боје јер оне удајом постају „мртве“ за своје родитеље, са обзиром на то да се у јапанској култури белом представља смрт. ${ }^{7}$ Као сума дугиних боја бело је и боја јединства ${ }^{8}$, али њен символизам може имати и супротно значење као што је недостатак храбрости и обмањивање. ${ }^{9}$ Црно је представљало мистерију, те тајновитост и мудрост Божију. ${ }^{10}$ Црно је и символ за тишину у смислу тајни које се не могу свакоме открити и најдубљих личних духовних искустава. ${ }^{11}$ Наративу смрти, као највећој мистерији, у многим културама придружена је црна. ${ }^{12}$

\section{Примери из старог века}

У сваком времену се кроз владајуће философске и религијске парадигме испитују теме попут божије мудрости, краја света, раја и пакла, васкрсења мртвих. Нови живот, односно васкрсење које представља символ трансценденције и надилажења људских моћи, био је и остао највећа тајна и највећа нада човечанства кроз историју.

У древном Египту је божија мудрост сликовно била сакривена тамом непознања као недоступна интелектуалном поимању. ${ }^{13}$ Према митологији, црна смрт претходи васкрсењу Озириса, Анубиса и Птаха. ${ }^{14}$ Божанства Озирис и Хорус су некада представљана у белој а некада у црној боји, што је предочавало то да се манифестују у

5 Томић 2012.

6 Исто.

7 McCaffery 1921, 42.

8 Исто, 40.

9 Исто, 45.

10 Исто, 46.

11 Исто, 47.

12 Wolchover 2011.

13 McCaffery 1921, 46.

14 Garden et al. 2011, 87 
времену. ${ }^{15}$ Озирис је у одређеним ситуацијама сликан са црним лицем и белом митром ${ }^{16}$, а Озирис, Анубис и Птах, као и друга божанства која су повезивана са смрћу и васкрсењем, имали су кожу у црној или зеленој боји ${ }^{17}$.

У митологији проналазимо још индикативних представа бесмртности и васкрсења. Код старих Јелина (Грка) ноћ је представљана као вео од звезда са два детета - белим (Време) и црним (Вечност). ${ }^{18}$ Када је бог медицине, Аполонов син Асклепије, толико узнапредовао у исцелитељским моћима да је могао да васкрсава мртве, због чега је господар подземног света Хад постао забринут, Зевс је Асклепија убио муњом. ${ }^{19}$ Вештини лечења Асклепија је подучио кентаур Хирон. Овај јелински мит обухвата коначну транзицију - полазећи од подземног света, низ се наставља преко бесмртности, све до светлости и људи. Прометеј, који жели да се домогне искре светлости да би је подарио људима, што се може поистоветити са божанском интелигенцијом, бива ослобођен мука у замену за смртну жртву - добровољно жртвовање бесмртног кентаура Хирона. ${ }^{20}$ Тајна је резервисана за изабране и имплицира жртву за забрањено знање. У случају Адама који постаје смртан, није пресудна казна, ни смрт, већ побијање нужности да црно бива трајно стање.

\section{Примери парадокса}

У циљу откривања распрострањености парадокса црног и белог, и то претежно мрака који тајанствено исијава и светлости која бива скривена тамом, биће изложени примери из психологије снова, историје науке, астрофизике, колористике, библистике и иконописа.

\section{Онирички парадокс - црно-бели снови}

Сневање се одвија на неуро нивоу и има одређених сличности са смрћу - збива се под окриљем ноћи, у мраку, затворених очију. ${ }^{21}$ Оно што се није догодило на јави, као што је садржај сна, ипак може постати предмет истраживања. ${ }^{22}$ Колорит снова спорадично привлачи пажњу истраживача из области психологије од прве половине 20. века. ${ }^{23}$ Првобитно опречни резултати студија по питању тога да ли већина снова садржи боје или сањамо доминантно у црно-белој варијанти касније су тумачени лошим одабиром начина прикупљања података од испитаника. Развој емпиријских истраживања кореспондирао је и са развојем сазнања у психологији снова. Током 50-их година било је психијатара који су сматрали да би снови у боји могли дати индиције за постојање менталних поремећаја. ${ }^{24}$ Резултати истраживања вршених током 90 -их указали су на то

15 McCaffery 1921, 47.

16 Garden et al. 2011, 405.

17 Исто, 87.

18 McCaffery 1921, 47.

19 Chevalier, Gheerbrant 1987, 730-731.

Срејовић, Цермановић-Кузмановић 1987, 57.

20 Chevalier, Gheerbrant 1987, 535.

Срејовић, Цермановић-Кузмановић 1987, 363.

21 Wolchover 2011.

22 Притом, парадоксална фаза сна, REM (rapid eye movement) фаза, овде није у фокусу.

23 Murzyn 2012.

24 Calef 1954.

Tapia, Werboff, Winokur 1958. 
да црно-беле снове углавном сањају људи старије узрасне доби ${ }^{25}$, да би анализе са почетка 2000-их довеле до детаљнијег закључка да старији људи, као и становници руралних подручја, сањају црно-бело због дуже изложености црно-белој телевизији која је утицала на њихову представу о сновима ${ }^{26}{ }^{27}$ У истом периоду долази и до напретка студија које су у вези са памћењем боја путем којих је у наредној деценији установљено постојање зависности између пријављивања снова у боји и способности визуелног представљања. Ова повезаност имплицира да је памћење снова директна последица наше могућности да их визуелно представимо, што обухвата и памћење боја. ${ }^{28}$ Само откриће могло би да буде решење за неусаглашеност између онога што су испитаници сањали и онога чега су се касније сетили.

Снови непознатог садржаја, такозвани бели снови, у скорије време су почели да привлаче пажњу научника. Иако чине трећину пријављених снова, били су занемаривани јер се сматрало да су то снови који су заборављени, те да не садрже користан материјал

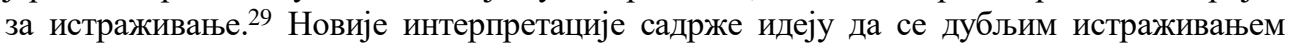
феномена белих снова и пропратних опсервација могу добити информације о природи сањања и људске свести. ${ }^{30}$ Научници указују на могућност да се из снова без форме, белих снова, добије садржај који би био од значаја за разумевање скривених аспеката нашег бића - наше таме.

\section{Епистемолочки парадокс}

Тама и наука о светлости су повезане кроз сигнификантне примере. У савременој епизоди науке, светлу, то јест зрачењу, се додељује и црни означитељ - не само у називу већ пре свега по смислу - тако да се користе изрази тамна енергија и тамна материја.

Осим савремене епизоде са тамном материјом и епизоде са позадинским зрачењем, са становишта парадоксалности, феноменолошки и гносеолошки је значајна и историјска епизода са открићем инфрацрвеног (ИЦ) зрачења. На основу тог примера може се пратити како се истраживачи упознају са тајнама „изласка зрачења“ и изгледом „белог“, овај пут у смислу зрачења, које долази из домена „црног“.

Невидљиви зраци су у 17. веку заинтересовали чланове Академије дел Чименто у Фиренци. ${ }^{31}$ Француз Едм Мариот (Edme Mariotte, 1620 - 1684) се упушта у разматрање сличне теме испитујући дистинкцију тамног и светлог зрачења, при чему тамно зрачење за њега представља зрачење тела које је загрејано али није ужарено. ${ }^{32}$ У 18 . веку швајцарски полихистор Ламберт (Johann Heinrich Lambert, 1728 - 1777) је екпериментално показао да се тамни зраци простиру на исти начин као светлост. ${ }^{33}$ Јавља се отпор таквом приступу, а највише је експониран став шкотског математичара и физичара Леслија (John Leslie, 1766 -

Murzyn 2008.

25 Stepansky et al.1998.

26 Schwitzgebel, Huang, Zhou 2006.

Murzyn 2008.

27 Murzyn 2012.

28 Исто.

29 Fazekas, Nemeth, Overgaard 2019.

30 Исто.

31 Mlađenović 1985, 181.

32 Исто.

33 Исто.

Рад постхумно објављен у књизи: Lambert 1779.

Mlađenović 1985, 181. 
1832) са основним, притом за ово разматрање и најиндикативнијим аргументом да појам невидљивог зрачења садржи унутрашњу противречност..$^{34}$ Овај низ, проширен достигнућима још неких значајних научника, води до Хершела (Friedrich Wilhelm Herschel, 1738 - 1822) који је 1800. године пред Краљевским друштвом у Лондону објавио своје експериментално откриће ИЦ зрачења. Осим Леслијевог здраворазумског закључка о споју неспојивог, о контрадикторности феномена и самог назива, овом разматрању се може додати и питање: шта све утиче на истраживача да прихвати постојање једног феномена који је наизглед окарактерисан противречношћу?

Из епистемолошког угла посматрано, епизода са ИЦ зрачењем садржи следећу поуку - завршетак једне врсте разумевања представља почетак другачијег начина гледања, а прелазак границе није без специфичне тежине, није баналан, већ захтева напор, храброст, али и инспирацију ${ }^{35}$. Имајући у виду колико је недоумица и расправа изазвало ово откриће, циљано се можемо запитати какви се тек ерминевтички изазови и научни парадокси могу очекивати ако се за тему узме проучавање - Васкрсења и Преображења.

\section{Три парадокса: космолочки, колористички и иконописачки}

Космолошки и астрофизички парадокс. Црно је слика универзума, али дан је бео. Изузимајући компоненту температуре неба коју носи атмосфера, дан има исту унутрашњу температуру неба као и ноћ. Парадоксално, та температура, то црнило, је прва светлост. Црнило неба садржи и астрофизички парадокс описан као Олберсов парадокс. Тама ноћног неба контрадикторна је постојању извора светлости звезда у свим правцима на небу, али је црнило ипак присутно због коначности брзине простирања светлости.

Парадокс мешања боја. Другачији приступи могу да изнедре диспаратне закључке. Такав пример представља процес мешања боја који у једном случају за резултат има бело, а у другом црно. Мешање боја може се извршити на два начина - адитивно и супстрактивно. Адитивно мешање боја засновано је на својствима оптичких процеса и настаје када се преклопе зоне светлости одређених боја. Преклапањем три зоне - црвене, плаве и зелене, настаје бела светлост. ${ }^{36}$ Насупрот томе, супстрактивна синтеза представља мешање пигмената, при чему се стапањем црвене, плаве и жуте добија ирна боја. ${ }^{37}$

Парадокс из иконописа. На људском лицу огледа се „светлост помешана са тамом“ човековог бића. ${ }^{38}$ Пред сликаром је људски предложак, живи човек који је уметност по себи и „уметност над уметностима“"39. На његовом лицу укрштају се и рефлектују богословска, иконописачка, антрополошка и психолошка мисао о црном и белом.

\section{Три иконе: Преображења, Распећа и Васкрсења}

Три фундаменталне одреднице црног и белог са несамерљивим синтетичким потенцијалом у фокусу су даље анализе. Реч је о догађајима који су трајно утицали на концепт црног и белог и трасирали приказе у којима се он појављује. То су: Преображење, Смрт на Крсту и Васкрсење.

34 Mlađenović 1985, 183.

35 Томић, Томић 2017.

36 Mueller, Rudolph 1972, 112.

37 Исто, 111.

38 Флоренски 2007, 32.

39 Исто, 33. 


\section{Преображене}

Прва икона коју су сликали иконописци ${ }^{40}$, и коју данас сликају је икона Преображења. Приказивање догађаја је повезано са исповедањем. У чину сликања те иконе исповеда се трансформација (метаморфоза) знања, почетак изласка из личне таме и усвајања белог (светлости) као крајњег опредељења. У оквиру теме белог, Преображењем се повезују време и вечност и објављује се тајна белих хаљина - и тајна светлог Лица које постаје видљиво. Светлост преображеног Лица постаје видљива и посматрачу иконе. У овој икони уједињују се искуства о светлости, о белим хаљинама, Сунцу и јављању Бога у светлости. Такође, Преображење наново актуелизује тајну сјајног облака.

\section{Смрт на Крсту}

Догађај који се одиграо од шестог до деветог часа по рачунању времена својственом новозаветном добу ${ }^{41}$ пратило је потпуно замрачење, тектонски поремећаји, цепање завесе. Од поднева до 15 часова на Земљи је била тама - најава црнила које долази људима и на космолошком и на антрополошком нивоу. Реч подне на грчком језику -

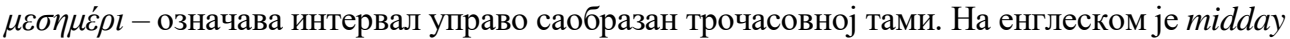
тренутак достизања врхунца светлости у дану који у случају смрти Господње, значајно је приметити - није светао. Парадоксално, а опет индикативно.

У часу када Сунчеви зраци додирују Земљину површину под најмањим углом, у часу када нема сенке, дошло је до потпуног помрачења. Недвосмислена символика указује на то да белина од Сунца нестаје у тренутку када би осветљеност требало да буде максимална. Дан постаје црн кад Господ умире. Проблематика међусобног односа таме и смрти, њихова повезаност и неодвојивост, продубљује се и постаје наглашена. Символичност је многострука - осим помрачења догађа се земљотрес, пуцање стена. ${ }^{42}$ У иконописачком смислу икона Распећа је усмеритељ ка јединој свељудској нади за избављењем у лику Богочовека - јединог Белог ${ }^{43}$, једине Светлости. Парадокси обасјане ноћи (Рођење) и мрачног поднева (Распеће) повезани су са старозаветном темом вере и избављења предоченом кроз стуб од огња ноћу и стуб од облака дању (2 Mој 13, 21). Тема Распећа доноси пред верне, и оне који то нису, ново упознавање са односом космичког белог (које губи сјај) и иконописачког црног (које ће засветлети).

У случају претпоставке да се Христовим данима страдања завршавају све црне ноћи (Хора нигре), открива се да ситуација није одвојена од личних граница. Сваком следи страдање. Помрачења ће, такође, бити у будућности (Отк 8, 12), а уследиће и интензивно сијање и велика тама.

\section{Васкрсење}

Смрт Васкрслог и силазак у ад је икона пред којом највише стрепе и застају иконописци и верни. Најзначајније за коришћење светлости у живописању је сазнање да су све иконе везане за Васкрсење. Крштење најављује Силазак у ад ${ }^{44}$, а црна

40 Евдокимов 2009, 203.

41 О часовима и конвертовању погледати у: Ракић 2004.

42 Ови догађаји тема су нових истраживања.

Погледати: Williams, Schwab, Brauer 2012.

43 Јединог трајно белог, неумрљаног, вечне Светлости.

44 Евдокимов 2009, 219. 
репрезентација учињена је кроз пећине. Васкрсење се најављује кроз Преображење, види се кроз (у) бело(м). Устајање из мртвих Једног, повлачи и васкрсење Многих. Објављивање је, такође, у белом - младић који говори мироносицама обучен је у беле хаљине (Мк $16,5-8)$, а два човека у белом најављују Други долазак Христов (Дап 1, 10-11).

\section{Надсуштаствена скривеност}

Црно и бело у религиолошком и теолошком дискурсу, као и њихови међуодноси ослањају се на не-до-краја-заокружен приступ. У случају проучавања јављања (откривења) и мистике не могу се применити принципи објективности, децидираности и искључивости. Притом виђења остају засебна тема, док је методологија којом се она истражују зависна од дисциплинарног, често и конфесионалног приступа, а закључци који се доносе могу бити диспаратни. Однос догађаја јављања са Белим и Црним, заправо однос са Богом, појављује се на примеру боговиђења по питањима светлости и примрака. У оквиру визија сусрећемо се са концептом који садржи парадокс који заузима посебно место у односу црног и белог - ради се о облацима и стубу од облака.

У Старом завету, у Псалмима, упућује се на облак и примрак: „Облаци и примрак су око Њега“ (Пс 96, 2). Мистика се артикулише (испољава) у парадоксалном новозаветном стиху - „Бога нико није видио никад: Јединородни Син који је у наручју Оца, он га објави“ (Јн 1, 18) - који спаја апофатички исказ у првом исказу („Бога нико није видио никад“) и катафатички у другом (,Јединородни Син који је у наручју Оца, он га објави“"). ${ }^{45}$ Може се извршити раслојавање те устврдити да је ово парадокс на три испреплетана нивоа - онтолошком као трансценденција и оностраност, сазнајнотеоријском као несазнатљивост, и лингвистичком у виду неизрецивости. ${ }^{46}$ Апофатичка мисао сведочи о познању које се одвија у примраку непознања. ${ }^{47}$ Божански примрак или

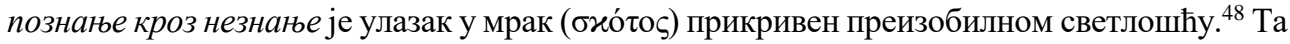
је светлост Божије јављање својим бићима. ${ }^{49}$ У Божанском примраку, према Дионисију Ареопагиту, живи Бог. ${ }^{50}$ Неприступна светлост (1 Тим 6, 16) заслепљујући је и непробојни блесак. ${ }^{51}$ Знање које негира себе као знање је знање о незнању о томе шта је Бог и знање о знаьу о томе шта није Бог. ${ }^{52}$

Божански примрак ${ }^{53}$ остаје парадоксално питање које се ставља у контрапозицију са јављањем Мојсију. Да ли је то контрапозиција у односу на визије у светлости, на прво богојављање Мојсију када се Бог јавља у светлости? Спрега између онога што се може и не може сазнати? До које мере се црно и бело могу докучити из догађаја јављања? Из ког разлога се појављују облащи, због чега су облаци означени сјајем, и зашто стуб од облака?

Присуство облака између извора светлости и осветљеног упућује да нешто није до краја осветљено, односно да није до краја разлучиво. Својим карактеристикама облак се налази између белог и црног, и нуди их оба. Бог је поставио мрак између себе и нас

45 Шијаковић 2002, 47.

46 Исто.

47 Исто, 52.

48 Лоски 2006, 90.

49 Исто.

50 Успенски 2009, 364.

51 Исто.

52 Шијаковић 2002, 52.

53 Григорије из Нисе 1993. 
(бxó $о \varsigma) .{ }^{54}$ Што је светлост боље скривена тмином и тежа за проналажење, интензивније нас привлачи. 55

Поредећи виђења светлости и мрака која је Мојсије имао током пута на врх Синаја, свети Григорије Ниски сматра да је мрак надмоћнији вид општења са Богом од светлости. ${ }^{56}$ Догађаји које притом пореди су умозрење светлости неопаљиве купине на почетку Мојсијевог путовања и мрак у који је проникао касније. ${ }^{57}$ Мојсијево путовање садржи и символизам стуба. Стуб од огња ноћу и стуб од облака дању црно-беле су представе.

Стуб је потпора за дом, храм, али и за аскете које су живеле на стубу, столпнике. ${ }^{58}$ Он символизије савршенство, и као такав је садржан у Песми над песмама $($ Пп 5,15$)$. Египатски џед стуб у култовима бога Птаха и Озириса подупирао је небо. ${ }^{59}$ Хераклови стубови представљају границу између Средоземног мора и Атлантског океана, односно најдаљу тачку на западу иза које није допуштено ићи. ${ }^{60}$

Стуб има космички и духовни символизам - моћ која осигурава победу и бесмртност, а карактерише га усправан положај, положај који повезује небо и земљу и упућује на тежњу ка савршенству. ${ }^{61}$ Стубови уоквирују врата, и указују на границу и крај $^{62}$ - било регуларну, очекивану границу или границу коју се не треба усудити прећи због уласка у области које не нуде трагаоцу заштиту. У крајњем, на прелаз из једног света у други.

\section{Завршно разматрање}

Са стране тумачења парадокса у природи, црно и бело у космологији и физици не морају бити парадокси, јер апсолутно црног и белог као таквих и нема. Као што је и разматрано - не постоје у космосу. ${ }^{63}$ Једино црно била би смрт - непостојање. Супротно, бело је вечно постојање, неуништиво, непропадљиво. Избегнути парадокс значи чекати васкрсење мртвих.

На основу разматраног може се закључити да употреба Белог са великим словом реферише на Преображеног, на Онога који се јавио на путу за Емаус, на Васкрслог, док употреба Црног реферише на Неспознатљивог, Који се открива преко својих енергија. Црно са малим словом указује на појмове који се односе на неспашене, а бело са малим словом на хаљине победника. Човек је кандидат за познање белог и црног, и о његовој кандидатури се расправља у црквеним студијама укључујући антропологију, религиологију, теологију као и друге хуманистичке науке. То је у етимолошком смислу очигледно јер на латинском језику candidas значи бело. Почетак трагања човека као кандидата је покајање - умиј ме и бићу бељи од снега (Пс 51, 7), а крај је светлосна белина спашених - онај који победи биће обучен у беле хаљине (Отк 3,5$)$.

54 Лоски 2006, 59.

55 Исто.

56 Исто, 64.

57 Исто.

58 Garden et al. 2011, 533 .

59 Исто, 532.

60 Срејовић, Цермановић-Кузмановић 1987, 464.

61 Garden et al. 2011, 533.

62 Исто.

63 Томић 2012.

Томић, Томић 2013. 


\section{Закључак}

Парадокс мрака који тајанствено исијава и светлости која бива скривена тамом садржан је у иконографији старог Египта и јелинској митологији. Старозаветни и новозаветни мотив Божанског примрака представља мрак прикривен преизобилном светлошћу. Након толико векова изучавања овог парадокса, као и саме символике црног и белог, њихове сличности, преклапања и антиномичности, толико различитих фаза и толико мислилаца, антрополога, теолога и осталих, који су живот завршили трагајући за разрешењем, тема и даље остаје актуелна. Разлог томе је што је она део личног трагања. Ови појмови се и даље намећу за истраживање, заједно са парадоксима које су им својствени, инспирацијом и границама. Њихове границе су везане за крајње (егзистенцијалне) догађаје: Васкрсење, Преображење, Рођење, Страдање, Гетсимански врт. Сви ови догађаји су од круцијалног значаја за иконописце, који се непрекидно налазе пред захтевом да на истој икони представе црнило амбиса, пећина, ада и светлост Преображења и Васкрсења.

\section{Литература}

Williams, J. B., Schwab, M. J., Brauer, A. (2012): An early first-century earthquake in the Dead Sea, International Geology Review, 54 (10), 1219-1228.

Wolchover, N. (2011): How 8 Colors Got Their Symbolic Meanings, Live Science, https://www.livescience.com/33523-color-symbolism-meanings.html 31.5.2021).

Garden, N., Olorenšo, R., Garden, Ž., Klajn, O. (2011): LAROUSSE - Mali rečnik simbola. Beograd: Laguna.

Григорије из Нисе, св. (1993): О божанском примраку, Источник, 2 (5), 64-65.

Евдокимов, П. (2009): Уметност иконе - теологија лепоте. Београд: Факултет за културу и медије Мегатренд универзитета, Висока школа - Академија Српске Православне Цркве за уметност и консервацију.

Jefferson, B. W., Schwab, M. J., Brauer, A. (2012): An early first-century earthquake in the Dead Sea, International Geology Review, 54 (10), 1219-1228.

Lambert, J. H. (1779): Pyrometrie, oder Vom Maasse des Feuers und der Wärme. Berlin: Haude und Spener.

Лоски, В. (2006): Боговиђење. Света Гора Атонска: Манастир Хиландар.

Mlađenović, M. (1985): Razvoj fizike, Optika. Beograd: Građevinska knjiga.

Mueller, C. G., Rudolph, M. (1972): Svjetlost $i$ vid. Zagreb: Mladost; Ljubljana: Mladinska knjiga; Beograd: Zavod za udžbenike i nastavna sredstva SR Srbije.

Murzyn, E. (2008): Do we only dream in colour? A comparison of reported dream colour in younger and older adults with different experiences of black and white media, Consciousness and Cognition, 17 (4), 1228-1237.

Murzyn, E. (2012): Imagery and memory for color and the reported color of dreams, International Journal of Dream Research, 5 (2), 108-113.

McCaffery, E. C. (1921): The symbolism of colour. London: W. Rider \& Son.

Ракић, Р. (прир.) (2004): Библијска енцииклопедија I. Србиње - Београд: Академија Светог Василија Острошког.

Срејовић, Д., Цермановић-Кузмановић, А. (1987): Речник грчке и римске митологије, друго издање. Београд: Српска књижевна задруга. 
Stepansky, R., Holzinger, B., Schmeiser-Rieder, A., Saletu, B., Kunze, M., Zeitlhofer, J. (1998): Austrian Dream Behavior: Results of a Representative Population Survey, Dreaming, $8(1), 23-30$.

Schwitzgebel, E., Huang, C., Zhou, Y. (2006): Do We Dream in Color? Cultural Variations and Skepticism, Dreaming, 16 (1), 36-42.

Tapia, F., Werboff, J., Winokur, G. (1958): Recall of some phenomena of sleep, Journal of Nervous and Mental Disease, 127, 119-123.

Томић, Б. М. (2012): Основа проблематике парадокса црног и белог: астрофизичко, физиолошко, теолошко и иконописачко становиште, Црквене студије, 9, 527-537.

Томић, Б. М. (2015): Светлост као конституент иконописа: хемијски, физички, физиолошки и теолошки аспекти. докторска дисертација, Универзитет у Београду.

Томић, Б. М., Томић, М. М. (2013): Мултидисциплинарна истраживања о црном и белом: границе, парадоксалности и уметничка (иконописачка) инспирација, Црквене cmудије, 10, 375-388.

Томић, Б. М., Томић, М. М. (2017): Различити приступи и нова мисаона парадигма: примери из историје физике, Војно дело, 69 (2), 389-399.

Успенски, Л. (2009): Теологија иконе. Света Гора Атонска: Манастир Хиландар.

Fazekas, P., Nemeth, G., Overgaard, M. (2019): White dreams are made of colours: What studying contentless dreams can teach about the neural basis of dreaming and conscious experiences, Sleep Medicine Reviews, 43, 84-91

Флоренски, П. (2007): Иконостас. Београд: Јасен.

Heyes, P. J., Anastasakis, K., de Jong, W., van Hoesel, A., Roebroeks, W., Soressi, M. (2016): Selection and Use of Manganese Dioxide by Neanderthals, Scientific Reports, 6, 22159.

Calef, V. (1954): Color in dreams, Journal of the American Psychoanalytic Association, 2, 453-461.

Chevalier, J. Gheerbrant, A. (1987): Rječnik simbola: mitovi, sni, običaji, geste, oblici, likovi, boje, brojevi. Zagreb: Nakladni zavod Matice hrvatske.

Шијаковић, Б. (2002): Пред лицем другог: фуга у огледима. Београд: Службени лист СРЈ, Никшић: Јасен. 


\section{Bojan M. Tomić \\ Milica M. Tomić}

\section{THE ULTIMATE PARADOXES OF BLACK AND WHITE}

In order to uncover the paradoxical nature of antinomic pair of black and white, so far their appearance in icon painting, science, mythology and symbolism has been examined, which has been done by considering key facts, findings, and paradigmatic episodes. Now, the examination has been brought to hermeneutical limits, taking into account the ancient mythology, history of science, biblical studies and iconography. Technological-coloristic paradox, cosmological and astrophysical paradox, paradox from epistemology, and oneiric paradox have been singled out. As the culmination, the icons of Transfiguration, Crucifixion and Resurrection have been considered, along with the Old Testament motif of the exodus from Egypt and the biblical motif of the cloud of unknowing. It has been concluded that research on black and white as an open topic, gives integrative and ultimate possibilities and challenges at all times. 